\title{
Az én szubjektivizációs megkonstruálása a Pályám emlékezete szövegében ${ }^{1}$
}

\section{Bevezetés}

Kazinczy Ferenc gazdag és terjedelmes életmüvével immár két évszázada foglalkozik a magyar szellemtudományi kutatások sora. E vizsgálatok legismertebb része az úgynevezett nyelvújításra irányul, de nagy múltja van a magyar irodalomtörténetben és fordítástörténetben betöltött helyéröl, történeti eseményekben való részvételéröl és szervezőmunkájáról szóló értelmezéseknek. Talán kevesebb figyelem jutott Kazinczy saját személyiségének nyelvi, irodalmi megkonstruálására, arra, ahogyan önmagát fölépíti, megjeleníti levelezésében és emlékirat-jellegü, próza- és stílustörténeti szempontból is jelentős müveiben. Az alábbiakban Kazinczy életművének eme összetevőjéről lesz szó. Közelebbről a Pályám emlékezete személyiségkonstruáló nyelvi eljárásairól, a világban-benne-lévő-szubjektum önreflexív beszédéről, beszédmódjáról. A Pályám emlékezete bizonnyal számos újdonságot mutat a korábbi korok magyar emlékirat-irodalmához képest. A Kazinczy-szöveg nem is emlékirat, sokkal inkább életesemények olyan elbeszélése, amelyet az elbeszélő nézőpontja határoz meg, az eseményekhez, azok további résztvevőihez és az így létrejövő történő helyzetekhez viszonyítva, saját (ön)reflexív elbeszélése módozataival. A nyíltan egyes szám első személyủ kiindulóponthoz (mint referenciaponthoz) a szubjektivizációs mozzanatok sora kapcsolódik módszeresen. A tanulmány az E/1. önreferáló és önreflexív konstruálási módjait, azon belül az ezekhez kapcsolódó, saját magára és a társszereplőkre vonatkozó szubjektivizációs elbeszélő módok, jellemzések, megjegyzések viszonyait elemzi, a kognitív nyelvtan elméleti és módszertani keretében. (A személyjelölés vizsgálatához lásd a Magyar Nyelvőr 2018. évi 3. számában A személyjelölés poétikája rovatcím alatt megjelent tanulmányokat.)

Kazinczy több önéletrajz-jellegü írást készített, és itt nem csupán a Pályám emlékezete több változatáról vagy a Fogságom naplója szövegéről van szó. Csupán említeni lehet e helyt, hogy Az én Életem címmel ismeretes önéletrajza esemény- és epizódtörténeteiben, a felidézett személyes élményekben nagymértékben fedi a Pályám emlékezete tematikai rendjét. Ugyanakkor Az én Életem más stílusban készült (ahogy az alcím ezt pontosan jelzi: „Barátimnak, Literatúránk' barátjainak, 's legközelebb gyermekeimnek"), magának Kazinczynak az önkonstruálása is legalább részben más nyelvi eljárásokkal történik meg. E müben ugyanis a közvetlen objektivizációs, áttétel nélküli, keresetlen véleménynyilvánítás jelentős, szemben a Pályám emlékezete közönségnek szánt, szépirodalmi igénnyel kidolgozott szubjektivizációs eljárásaival.

A jelen tanulmányban a Pályám emlékezete 1828-ban a Tudományos Gyüjteményben „Pályám’ Emlékezete” címmel megjelent szövegváltozatára, annak szövegrészleteire hivatkozom, a kritikai kiadás szövegközlése alapján (vö. Kazinczy 2009); az idézetek utáni oldalszám e kiadás helyeit jelöli. A Pályám emlékezete cí-

1 A tanulmány az NKFIH 129040 A magyar nyelv igei konstrukciói címü kutatás pályázati támogatása keretében készült. 
men megnevezhető szövegváltozatok száma hat, amely változatok szövegszerüen igen nagy átfedésben vannak egymással: „A [Pályám emlékezete I-VI.]-ban olyan panelszerúen elmozduló szövegelemeket láthatunk meg, amelyek ha elmozdulnak is, alapvetően megtartják szerkezeti, szintaktikai és lexikai kidolgozásukat, felépítésüket, és e szövegrészek következetesen megfeleltethetőek egymásnak" (Orbán 2009: 789). A szövegközlés részleteire lásd a kötet sajtó alá rendezőjének jegyzeteit (Orbán 2009).

\section{A korszak müvészetbölcseleti háttere}

Minden emberi cselekedet a maga közegében, szociokulturális kontextusában megy végbe, mind a cselekvő(k), mind más érintettek számára és nézőpontjából. Kazinczy Ferenc életmüve és az itt tárgyalt Pályám emlékezete szempontjából ez kivált érvényes és számba veendő. A 18. század utolsó harmada és a 19. század első néhány évtizede az európai művészetben és bölcseletben közismerten a klaszszicizmusból a romantika felé tartó korszakként van számon tartva, már a kortársaknak is. Illetve a francia kartéziánus racionalizmus és az angolszász Locke-féle empirizmus mellett mind hatásosabb a Leibnitz-féle idealizmus, majd Hegel, de főképp Herder, Goethe, Schelling, a Schlegel testvérek munkássága.

A klasszicizmus egyik fő elve, a különbözés egysége, mindinkább megmutatta egy fő jellemzőjét: a kifejezés gazdaságossága, a mesterségbeli tudás, a retorizáltság valójában ellentétek és feszültségek egysége, amely egység egyre kevésbé maradt fenntartható (vö. Wellek 1970: 5-28). Ebben a folyamatban jelent meg a múvészet elméleti megközelítéseiben az organikusság, amelynek során a fizikáról (a matematikai rációról, az ész szabályairól) a biológiára tevődik át a figyelem középpontja. ${ }^{2}$ Az irodalmi müfajok rendje egyre inkább egyediség és változatosság keretében a biológiai fajok sokféleségének analógiájára lett értelmezve.

Míg a klasszicizmus a természet utánzását hirdette (Arisztotelész nyomán), az egyetemest, az embert mint olyant, a tipikust, és nem az egyedit és lokálist előtérbe állítva, ahol az irodalomnak törvényei vannak, az észre és a tapasztalatra alapozva, addig a rá következő fő irány inkább a szubjektív fontosságát, a líraiság alapállását, az ego egzaltáltsága kezdte hirdetni. Ez utóbbi számára az inspiráció, a képzelet, az invenció immár nem az örök mimetikus múvészi szabályok szerint müködik, hanem az autoritás, ész helyett az ízlés irányítja. A szépség egyetemes és örök fogalmával szemben a helyes döntés ösztöne válik a fö müvészi alkotóerővé, amely tanulható és spontán is lehet (Wellek 1970: 24). A klasszicizmus elvárt egyetemes müveltségen alapuló intellektuális teljesítménye mellé, helyébe a kreatív géniusz lép, fokozatosan.

Ez az a közeg, amelyben a müvészet és közegeként a kultúra történetisége és nemzeti egyedisége és annak megjeleníthetősége jelentőséget kap, háttérbe szorítva az irodalomnak a klasszicizmus által kijelentett fó célját, a morális megtisztulást.

2 Lásd példaként a Magyar Nyelvőr jelen számában Pethő József tanulmányát a korszak organikus metaforikus nyelvértelmezéseiről. 
A magyar irodalom a 18-19. század fordulóján legjobb alkotói révén ugyanezt az utat járta be: a klasszicizmusban benne állt, de a személyiség alkotó cselekvését, az ahhoz való jogot és kötelességet már a klasszicizmus normatív szemléletével szembe is helyezte (Szegedy-Maszák 1980). A részletes bemutatásra itt csak utalni lehet, egy fejleményt azonban érdemes kiemelni, a Pályám emlékezete egy vonatkozásában: jellemző eljárásként jelent meg vers és próza egymásba fordíthatósága a korszakban (Szegedy-Maszák 1980: 64-5). Nem csupán átírásról van szó, hanem a kétféle beszédmód közötti átváltásokról és átalakításokról, Ányos, Bessenyei és Csokonai müveiben. E fejlemény alakította a magyar prózaritmus kidolgozását, és a prózaritmus Kazinczy prózai írásainak fontos jellemzője.

\section{Kazinczy életmódja mint a Pályám emlékezete egy alapja}

A szerző életrajza nem lehet közvetlen tényező egy irodalmi mü értelmezésében, még emlékirat esetében sem (ahogyan Kazinczy itt vizsgált műve annak tekinthető - erről lásd alább). Kazinczy saját jól dokumentálható életvezetésével saját történeti korában azonban mások számára demonstrálva alternatívát mutatott, egyfajta megoldási módot a rendi társadalom már nehezen tartható szociokulturális mintáival szemben (a társadalomtörténeti feszültségekre és változásokra lásd Gergely szerk. 2005: 57-123, 154-90).

Kazinczy Ferenc egész életében dolgozott, nemes ember létére a korban szokatlan módon, méghozzá „civil” tevékenységet folytatott, egyszemélyes irodalomés kultúraszervezőként. Úgy dolgozott egész életében, hogy azért jövedelmet nem kapott. E viselkedésmód egyértelmüen a személy és környezete kölcsönhatásán alapult, méghozzá a viszonynak a személyiség, jelen esetben Kazinczy tudatos és tervezett alakításával, irányításával. Kazinczy igen érzékeny volt személyes és müvészi autonómiájára, ezt azonban egyértelműen saját környezetének (mint ez autonómia közegének) szelekciójával és alakításával tartotta fenn, a szociális és müvészi modernség felé tájékozódva (az autonómia ilyen értelmezésére vö. Luhmann 1998: 776-88). Ennek feltételéül és megvalósulásaként Kazinczy például a kortárs magyar kultúrában újszerü módon bánt az idővel: időbeosztása a feladatokhoz volt kapcsolva akkor, amikor a többség még a természeti időhöz mérte a tevékenységeit. Egy másik fontos tényezőként levelezésével kilépett a provinciából, a lokalitásból, teljes hálózatot hozott létre a hiányzó társadalmi szintü helyett is. Kazinczy ezáltal hozzájárult a modern magyar nyilvánosság létrehozásához. A művelődés iránti igénye, az általa is művelt önképzés fontossága közismert róla. Mindez a polgárosulás felé mutató jellemző, amely nem csupán megmutatkozik a Pályám emlékezete beszédmódjában, hanem részben éppen ez a beszédmód hozza létre. S e tényezők fölemlegetése nem eszményítés, inkább jelzi azt a feszültségviszonyt, amely Kazinczy saját életfelfogásában is megmutatkozott, hiszen e polgárosuló irány nem akadályozta őt a rendi alkotmányosság több tekintélyi, társadalmi alá-fölé rendeltségi szabályának és szokásának a megtartásában. 


\section{Nyelvi konstruálási módok a Pályám emlékezete szövegében}

Kazinczy alakilag saját életét beszéli el a Pályám emlékezete szövegében, nagyjából annak megírási idejéig. E kép azonban leegyszerüsíti a mü értelmezhetőségét. A Pályám emlékezete az elbeszélés mellett ugyanis azonos mértékben magának az elbeszélőnek a nyelvi megkonstruálása. E megkonstruálás a nyelvi megformálás általi értelemszerkezetek létrehozásában áll, és eredménye egy személyiség körvonalazása, egyedi események látszólag időben elrendezett és elbeszélt szekvenciájának a formájában. Ez a megkonstruálás nem fikció, de nem is dokumentum, hanem olyan irodalmi igényü szöveg, amely a személyiséget nem pusztán én ez és ez vagyok vagy az én történetem ez típusú kijelentésekkel mutatja be külsőlegesen, hanem belsőleg. A bensőség pedig nem érzelmi kiáradásokban, lírai megszólalásokban mutatkozik meg, hanem olyan bennfoglalt nyelvi mủveletekkel, amelyek implikált szubjektivizációs eljárásaikkal az elbeszélt eseményt egyrészt tárgyilagosan leírhatóvá teszik, másrészt ellenkező hatással a saját elbeszélő nézőpontot közvetve, de hatásosan érvényesítik.

A mindenkori beszélő valamilyen perspektivált, többnyire a saját nézőpontbeli kiindulópontjából felépülő viszonyban áll saját szövegével. A szöveg és a megértett beszédhelyzet, valamint a beszélő közötti kapcsolatot a nézőpont vagy az episztemikus lehorgonyzás mellett a szubjektivizáció is kifejezi. A beszélő mint szubjektum és a mondat által kifejezett jelenet résztvevője mint szubjektum megkonstruálása, azaz mondatbeli nyelvi kifejezése közötti különbség vagy azonosság a szubjektivizáció és az objektivizáció jellemzőiben mutatkozik meg (vö. Benveniste 1971). Általános értelemben a szubjektivizáció a beszélő vagy valamely más cselekvő nem kifejtett, azaz bennfoglalt jelenléte, cselekvésének, attitüdjének vagy hiedelmeinek a rejtett kifejezése által, egy mondatban vagy szövegrészletben, anélkül, hogy a mondat vagy szövegrészlet nyílt és objektivizált résztvevőjévé válna (ehhez lásd Athanasiadou-Canakis-Cornillie eds. 2006; Langacker 2006; Lyons 1982; Traugott 1989, 1995; Athanasiadou-Canakis-Cornillie 2006; Kugler 2013; Tolcsvai Nagy 2017a: 306-9; 462-6).

A szubjektivizáció során a konceptualizáló szubjektum, leggyakrabban a beszélő - mint a mondatbeli jelenet fogalmi megalkotója - rejtetten jelen van a mondatban, de az általa megkonstruált jeleneten kívül marad. A szubjektivizáció a rejtett konceptualizáló jelenlét jelölése, amelyre az önmagára irányuló figyelem (önreferencia, önazonosítás) általában teljes hiánya jellemző, miközben a kifejtett jelenet mint a konceptualizálás célja feltűnő, jól körülhatárolódik, megértése kellő pontossággal történhet, vagyis objektivizált (Langacker 2006: 18). Aszimmetria van a szubjektivizált és objektivizált elemek között. Egy kifejezés jelentése általában tartalmaz szubjektívan és objektívan konstruált elemeket. A szubjektívan konstruált elemek közé tartozik elsősorban a beszélő és másodlagosan a hallgató, a mondatbeli jeleneten kívüli konceptualizáló szerepükben.

Kazinczy pontosan ezt a kettősséget működteti kifinomult beszédmóddal a Pályám emlékezete szövegében: egyszerre beszél el objektivizáltan egy-egy eseményt, miközben saját magát egyszerre objektivizáltan és szubjektivizáltan jeleníti meg, 
és egyúttal egyes értékelő vagy perspektiváló elemeket implikálva, szubjektivizációs módszerrel konstruál meg. Az alábbi idézet röviden is példázza e beszédmódot:

(1) „Eltöltvén esztendőt a’ Poeticában, most már a’ Rhetoricába kelle általvitetnem. De én kértem anyámat (atyám ekkor fogott nagyatyámmal Nyitrába járni) hagyna veszteg még eggy esztendeig. A' férfilelkü asszony elakada kívánságom’ szokatlanságán, 's bejött Patakra, hogy a' Professorok' tanácsával élhessen; rettegett, hogy hátra maradtam, 's azért akarok vesztegleni" (476).

Az 1771. évről, a sárospataki kollégiumban töltött évekről szóló részletben a fő esemény a diák Kazinczy kívánsága és ellenállása: még egy év poétikát kívánt tanulni, ez kötötte le igazán. Ezt alapvetően tárgyilagosan, objektivizálva beszéli el, mintha mással történt volna a kívánság és annak elutasítása. A történetnek maga a főszereplője azonban az elbeszélő, aki tehát egyszerre főszereplő és elbeszélő. Ezt a kettősséget az E/1. lehorgonyzó igei és birtokos toldalékok jelzik, amelyek egyszerre jelölik a színen lévő, ott cselekvő szereplöt és egyúttal a diskurzustér középpontjának (az alapnak) legfőbb elemét, a jelenetben nem részt vevő beszélöt, akihez a megkonstruált esemény le lett horgonyozva. Az E/1. tehát egyszerre objektivizált és szubjektivizált. Az idézett részből érdemes még a férfilelkü asszony kifejezést szemügyre venni. A férfilelkü melléknév Kazinczy anyjának olyan összetett jellemvonásait hozza felszínre, amelyek igen lényegesnek bizonyulnak az elbeszélő számára, ugyanakkor azokat implikálva jelzi, nem fejti ki részletesen, felsoroló módon. A férfilelkü melléknév egyszerre utal az anya határozottságára, elszántságára és döntést hozó képességére, egyúttal pedig (és itt jelenik meg a teljes erővel a szubjektivizációs mozzanat) az elbeszélőnek arra a véleményére, hogy családi ügyekben a határozott döntés a férfié, nem a nőé.

Az ekképp jellemezhetö elemi és az összetett jelentésképzésnek az aktusai közé tartozik az én önreferenciális és önreflexív megjelenítésének specifikus módja, az elbeszélés lehorgonyzó deiktikus igeidőinek (főképp a kétféle múlt időnek) az alkalmazása, valamint az események további résztvevőinek nyílt és implikált jellemzése, az elbeszélő hozzájuk való viszonyának szubjektivizációs módja. Az alábbiakban e három jellemző bemutatása olvasható.

\subsection{Az én, a szubjektum}

Bizonnyal az elbeszélő szubjektum, az én közvetlen és jelölt nyelvi megformálása az egyik legfontosabb összetevője az én megkonstruálásának a Pályám emlékezete szövegében. Az én itteni szerepét két értelmező nézőpontból érdemes megközelíteni: az egyik a szubjektum modernségbeli interpretációja, a másik a Pályám emlékezete és az önéletírás viszonya.

A 18. század végén a személyiség, az individuum müvészi és kulturális előtérbe kerülése és a közösséggel (immár egyre inkább a nemzettel és kultúrájával és nem az uralkodóval) való kölcsönös viszonya a szubjektum önreferáló és önreflexív tényezőit és lehetőségeit helyezte a figyelem elöterébe.

Innen nézve szubjektum a hermeneutikai filozófia értelmezésében az az entitás, amely „létében megérti magát”, vagyis a jelenvalólét (más fordításban ittlét, Dasein) 
(Heidegger 1989: 142). Másképp fogalmazva: ,a szubjektum maga az önreferencia a megismerés és a cselekvés alapjaként” (Luhmann 1998: 868). A szubjektumot ekképp a történetiség jellemzi. A szubjektum az alapul szolgáló, „hordozó” valóság, amely lényegében egy „rajta nyugvó”, „hordozott” valóságra való vonatkozást fejez ki. Ugyanakkor ,,az ismeret úgynevezett szubjektumának ugyanaz a létmódja, mint az objektumnak, [...] bár a szubjektum-objektum ellentét helyénvaló ott, ahol a res cogitansszal szemben az objektum valami egészen más: a res extensa" (Gadamer 1984: 361).

A hermeneutikai megközelítés azt hangsúlyozza, hogy a megismerő és cselekvő ember többek között a környezetével összekapcsolódva az, ami és aki, és többek között már eleve azért olyan, mert abban a közegben létezik, ahol létezik. A világbeli dolgok és jelenségek megismerése e dolgok és jelenségek között elhelyezkedő ember által lehetséges, és nem valamely külsőleges, abszolút tárgyias nézőpontból. A szubjektum-objektum racionalista eredetü, objektivista klasszicista szembenállása feloldódóban volt a 18. század végén, és ez a folyamat összetalálkozott Kazinczy személyes beállítottságával.

Az E/1. prototipikusan a beszélő. A beszélő a referenciális jelenetben önmagát nemcsak E/1.-ként, hanem egyúttal kívülről is látja, ,ugyanabból a »külső« szempontból nézi, mint amelyből a másik személyt és a tárgyat" (Tomasello 2002: 107). A Pályám emlékezetében rendszerszerüen nincsen közvetlen, nyílt reflexió magára az elbeszélésre mint müveletre, ez a tényező is implikálva van beépítve a szövegbe, az E/1. jelöltségén és összetett tartalmán túl például a rövid, gyakran anekdotaszerü történetelbeszélések és leírások formájában.

Az E/1. beszélő konstruálása a kettős nézőpontból a következő összetevőket tartalmazza:

- a konceptualizáló beszélő a diskurzustérben az alap,

- a jelölt beszélő a színen az elsődleges szereplő, referenciapont, az alaphoz lehorgonyozva,

- a jelölt beszélő:

a beszélő nézőpontjából

E/1. én

a) önreferáló (a beszélő számára) objektivizált

b) deiktikus szubjektivizált

- a hallgató nézőpontjából

E/1. te

a) referáló (a hallgató számára) objektivizált

b) deiktikus szubjektivizált

A Pályám emlékezete mondataiban, szövegrészeiben ezért tünik olyan természetesnek az E/1. nyelvtani alak: az elbeszélő a jelzett kettősségben formálja meg 
az eseményeket: egyrészt kívülről szemlélve saját magát mint cselekvőt vagy mások cselekvéseinek (nyelvtani és valós) elszenvedőjét objektivizálva, másrészt elbeszélö szemlélöként, történetkonstruálóként belülröl láttatja ugyanezt, szubjektivizálva. Ez éppen azért lehetséges, mert miközben az E/1. szubjektivizált volta természetes, addig a másokról, közös szereplőkről való szubjektivizált beszéd viszont kevésbé. Ehhez képest jelennek meg a többi szereplő E/3. alakú megnevezései és említései, illetve az egyenes idézettségü párbeszédekben az E/2. alakok; például a (2) részletben (510).

(2) „Midőn én 1789. Novemb. ismét eggy útat tevék Bécsbe, Pestre érvén, megszállottam a' Fejér-Farkas fogadóban (illy fogadó ma nincs) 's cselédemre bízám, válasszon szobát; magam mentem Rádayhoz. Áltellenben lakott a’ fogadóval azon háznál, hol ezidén Kulcsár Ujságírónk meghala; ő a' felső soron. A'grádics'rostélyajtaját nyitva lelvén, felléptem a' folyosóra. Ráday elméne mellettem, szemeink összeakadtak, rám ismert, de az ötet el nem akasztotta; ment, 's veszekedett cselédjével, hogy belé hangzott a' ház. Megfordúljak e, bemenjek e, nem tudtam; de minekelötte tanácsot adhaték magamnak, beléptem a' nyitva hagyott ajtón, 's az eggyik ablakszögbe vonám-meg magamat."

Az E/1. beszélő itt (mint a szövegekben általában) feltünő, aktivált, könnyen hozzáférhető entitás, emberi lény, a figyelem középpontjában állva, folyamatos referenciapontként funkcionálva, ahonnan kiindulva a további ismeretelemek hozzáférhetővé válnak. Az olvasó végig tisztában van azzal, hogy egyetlen elbeszélő szólal meg, az E/1. rá vonatkozik, úgy, ahogy azt a mü címe és a vele együtt álló szerzői név meghatározza.

Emellett a Kazinczy-mü mint írott szöveg esetében az elbeszélő az olvasó számára közvetettebben jelenik meg, a te közvetlensége háttérbe szorul, ám ezt pótolják a szubjektivizációs eljárások, amelyek bennfoglaltan mégis közel hozzák az olvasóhoz az elbeszélő nézőpontját. Ez tapasztalható a föntebb idézett (1) szövegrészlet férfilelkü asszony kifejezésének megformáltsága által.

E ponton kapcsolható az elemzéshez az önéletírás szövegtípusa. Az önéletírás egyik fö típusában az elbeszélő személyisége mintegy teljes mértékben háttérbe szorul, vagy meg sem jelenik (például Montaigne esetében), míg a másik fő típusban a személyiség globális egysége a kiinduló alaptétel (erre példa Rousseau írása) (vö. Nagy 2007: 560). Az első esetében az élettörténet (a sors) vagy az élettörténetből levont általános következtetések, bölcsességek, világmagyarázat a meghatározó, míg a második esetében a személyiség belső története, morális és érzelmi küzdelmei döntőek az események folyamán. Másrészt több változata ismeretes a dokumentálás (,referencialitás”) és a fikció közötti önéletrajzbeli viszonynak, amely akár az író szubjektum eltünését is eredményezheti az írásban mint gyakorlatban (Nagy 2007: 559).

A Pályám emlékezete olyan önéletírás, amelyet a dokumentálás szervez, az események mint életepizódok kronologikus elbeszélésével. lényegesebb azonban, hogy a mű az önmegfigyelés aktusaira is épül, amelyet a visszafogott, implikált bensőségesség jellemez, és ahol az élettörténet a személyiség története, de nem tekinthető vallomásnak. A személyiségtörténetet általános esztétikai és morális elvek fogják keretbe, e keret azonban nem kíván teljes világmagyarázatként megjelenni, inkább a személyes cselekvés autentikus közegeként formálódik meg, már a Pályám emlékezete legelején, 
a képzés és az önképzés természetes elvártságának nem túlhangsúlyozott, de tudatosan számon tartott elemeiben. A Kazinczy életvilágbeli döntéseiben is megjelenő esztétikai világszemlélet (vö. Tolcsvai Nagy 1996), a világ dolgainak a személyes ízlésen történő átszürése így kapja meg a fontosságát.

Ilyen értelemben Kazinczy írása különbözik a klasszikus emlékiratoktól éppúgy, mint a korábbi magyar hagyományoktól (Bethlen Miklós vagy Bethlen Kata önéletírásaitól), de éppígy a kortárs Coleridge múvétől is (Biographia, 1817).

A Pályám emlékezete tehát nem nagy elbeszélés, azaz nem „külső” történetírás a sorsdöntő nemzeti vagy világesemények értelmezéseként, a világegyetem értelmének kereséseként. Az eseményelbeszélések gyakran kis részletekre összpontosítanak, amelyek jelzik az elbeszélő spontán élményen alapuló, ám az elbeszélésben pontosan felépített nézőpontját, egyúttal metonimikusan és metaforikusan is rávilágítanak egy esemény globálisabb és lokálisabb vonatkozásaira. Ilyen leírás II. József sárospataki látogatásának az alábbi részlete, amely kitér a császár ruhájának foltozott könyökére (475-6):

(3) „Eggyszerre hír terjede-el, hogy II. József (1770. Máj. 20-d.) Patakon fog ebédelni. Más atya megeléglé vala, ha gyermeke a' Császárt szekerében pillanthatta volna meg: ő bejöve, 's a' jobb Nézők közzé vezete-el. Megérkezének a' szekerek; a' Császár beméne szobájába; de ki is jött, porszínü felső kaputban, hónja alá fogván zöld viaszasvászonnal bevont félsphéra-formájú úti-kaskétját, széles ellenzővel; 's deák nyelven tudakozá, melly helyeken fog váltani lovakat Munkácsig; azt feljegyzé Zsebkönyvébe, meghajtá magát, 's elzárkozott, hogy ebédig dolgozhassék. Ebédje alatt megengedteték a' bémenés, a' fériaknak háta megé, az asszonyoknak szembe. Maga, a' hét személyre terített asztalnál, jobbra, az utolsó széket foglalta-el; balja mellett sógora ült, Albert Lengyel Kir. 's Tescheni herczeg, e' mellett Lascy (olv. L a s z c z y), legfelül Nostitz Generalisok. A' Vice-Ispán nékünk is, gyermekeknek, megengedé, hogy a' Császárnak tányért nyújtsunk. Álmélkodva látám itt, hogy könyökén foldozva volt a' zöld uniformis; még inkább álmélkodva, midőn a’ bort soha nem ivó Fejedelem, a' bor' színét tekintvén, ezt kérdé: I s t e v i n u s To k a j i n u s? útálva a' vesztegetést és czifrát, példát akara adni a' foldozott-könyökủ kabáttal."”

De ez nem is a belső érzelmi élettörténet, nem a szelf históriája. Inkább a közvetlen élmények, tapasztalatok általi folyamatos reflexió és önreflexió, önmegismerés - saját személyiségét állítja fel, az olvasó számára fokozatosan, de visszatekintve. Az elbeszélésben egyszerre érvényesül az érintett szereplőkkel szembeni elkülönülés, távolságtartás, egyben közvetlen együtt cselekvés, a beleélés, amely a vele megtörtént események további szereplőinek nézőpontját is bennfoglalja, mint a (2) részlet folytatásában, a Ráday gróf házában zajló konfliktus további leírásában (510):

(4) „Az Öreg jött, lármázva mindég, 's hozta író-tollát jobbjában, leült, folytatta az írást, felkölt, kiment, ismét elkezdé veszekedéseit a' cseléddel, ki addig vala ingerelve, hogy a' dudogást visszaadá. Úgy tetszék, rá-ijeszte a' cseléd, mert most valamivel csendesebben tére-vissza; leült, írt, 's elökiáltá a' tiszteletlent. De illy okos, illy öreg ember, hogy lőhet illy bakot, hogy kezébe adják a' levelet, és még sem kérdi-meg, hogy a' válaszért eljönnek e, vagy azt hova vigyék. Lássa Kend, az ember beteg, segédemre van szüksége; tudom hogy Budán tartózkodik, de nem tudom hol; küldeném neki a' segedelmet, 
's nem tudom hova; a' Kend' lelkén fekszik a' vétek, hogy eggy szegény ember segéd nélkül marad. - Az elkinzott cseléd nem láta jobbat mint ezt felelni: Ne higyjen Nagyságod a' fertelmes németnek; ha beteg volna nem hozta volna maga ide egészen Budáról. Rá-szoktak Nagyságodra; azt hazudják hogy bajok van, mert tudják hogy nem mennek-el üresen. - 'S ekkor vala még a' nagyja!'

Az elbeszélő beleélő eljárásával, együttérzően és kissé ironizálva is perspektiválja az olvasó számára a történetbeli cseléd helyzetét, a tiszteletlen és az elkinzott cseléd nominális kifejezésekkel. Ezt erősíti az Öreg bizalmas és rokonszenvező kifejezés is az elbeszélő részéről Ráday felé, a patriarchális viszonyuk metonimikus jelzéseként. Jól látható tehát, hogy az elbeszélő saját nézőpontja, saját kiindulópontja mint referenciapont nagymértékben meghatározza a konstruálás módját, a beszédmódot.

\subsection{A lehorgonyzott igeidő perspektiváltsága}

Az emlékirat rendesen múltbeli események elbeszélése. A múltbeli eseményeket múlt időben szokás elbeszélni. Ez a látszólag grammatikai és narrációs jellemző Kazinczy írásában összetett és változatos megvalósulásokat mutat. Az -á, -é jelölésü elbeszélő múlt és a - $t$ jelölésű egyszerü magyar múlt időket Kazinczy bőségesen váltogatja. És bár nem fedezhető fel a két múlt idő között szigorú funkcionális elkülönülés, a fö irány jól kirajzolódik, mint az alábbi részletben (478):

(5) „Egy nap (1774.) tavasz' elején atyám 's anyám látni jövének. Minthogy Regmecz Patakhoz csak három órányi távolban van, még az nap haza tértek. Szokatlan aggodalom rohana rám elválásokkor. Felszökém szekerekre, 's messze kísértem el Újhely felé.

Harmad nap múlva üresen jöve szekerek azon izenettel, hogy a' Katonai-Orvost küldjem ki, mert atyám rosszúl van, 's a' Vármegye' Orvosa falura vitetett. Mentem én is, 's ott maradék. - Mártzius' 20-dikán elhala, élte' 42-dik esztendejében; 's 38 esztendős Özvegyét hét élő gyermekkel hagyá, a' nyolczadik öt holnap múlva leve meg."

A két múlt idő értelmezéséhez az alábbi tényezők figyelembevétele szükséges.

- a nyelvtani idő összefügg az idő általános (nem csak nyelvi) feldolgozásával;

- a két múlt idő szignifikáns mértékben különbözött a 19. században is, funkciójuk egymáshoz viszonyítva müködött;

- a múlt idők, mint az igeidők általában, csak az ige belső időbeliségével és a mondat időszerkezetével együtt értelmezhetők.

Az igeidőt nem hozzáragasztjuk az igéhez, hanem az ige által kifejezett időbeli folyamatot a beszélő beszédidejéhez viszonyítjuk a mondatban.

Az inherens idő a folyamatot kifejező nyelvi szerkezetek jelentésében pillanatnyi állapotok (azaz most-pontok) sorozata. Például a megy ige járással végrehajtott helyváltoztató mozgást fejez ki, amelyet a mozgó élőlény saját akaratból és energiaforrásból hajt végre. A megy ige a meghatározott mozgást időben fejezi ki, a moz- 
gást pillanatnyi állapotok sorozataként. Ezek a pillanatnyi konfigurációk váltanak át sorban egymásból a következőbe. Ennek a jelentésnek a megkonstruálása szekvenciális feldolgozással (szekvenciális letapogatással, szkenneléssel) történik meg (vö. Langacker 1987, 2008). Az egymásra következő pillanatnyi állapotok időbeli feldolgozása a szekvenciális letapogatás.

Az igének tehát kétféle ideje van: az egyik a belső idő (az inherens temporalitás), a másik a mondatbeli igeidő. A belső idő minden szótári igére jellemző, hiszen minden ige folyamatot fejez ki, amely idöben történik: megy, áll, van, esik. Az igék azonban nem magukban állnak a szövegben, hanem mondatszerkezetek középponti részét képezik, ahol a beszélő nézőpontjának, konstruálási módjának, beszédidejének megfelelően valamilyen igeidőbe kerülnek, amelyet alakilag is kifejezünk. A megy, áll, van, esik ige folyamatot fejez ki, amely folyamat megtörténhet a jelenben, megtörténhetett a múltban, és bekövetkezhet a jövőben is. A kétféle idő egyszerre és egymásra hatva érvényesül a mondatban, a szövegben, úgy, hogy összekapcsolódik egy harmadik idővel, a beszéd megértésének az idejével.

Miképp a korábbi, a kódexek korából származó szövegek elemzései is mutatják, az elbeszélő múlt a beszélőhöz képest episztemikus közvetlenséget, az átélést és a szemtanúságot fejezte ki, míg az egyszerủ múlt a beszélőtől eltávolított múltat. Vagyis az elbeszélö múltban megkonstruált történet azt a hatást kelti, mintha a beszélö élőben közvetítené az eseményt, holott az már korábban megtörtént. Az elbeszélő múlt alkalmazását a beszélő szubjektivizációs eljárással hajtja végre: az episztemikus közvetlenséget vagy a szemtanúságot impliciten ezzel az igeidővel jelzi, azaz bennfoglalt jelenléte, attitűdjének vagy hiedelmeinek, nézőpontjának a rejtett kifejezése által, egy mondatban vagy szövegrészletben, anélkül, hogy a mondat vagy szövegrészlet nyílt és objektivizált résztvevőjévé válna (vö. Traugott 1989; Langacker 2006; Kugler 2013).

A két múlt idő összehasonlítása során feltünik, hogy fontos tényező a beszélő (vagy konceptualizáló) implicit hiánya az egyszerü múltban és implicit jelenléte az elbeszélö múltban.

E variabilitásnak az episztemikus közvetlenség mellett másik megnyilvánulása az evidencialitás: a megnyilatkozói tudásnak, az evidencia forrásának, típusának nyelvi jelölése (lásd Aikhenvald 2004; Kugler 2015) - az egyszerű múltban ennek nincsen jele, az elbeszélö múltban közvetlen evidencialitás, szemtanúság esetén gyenge vagy közvetett változat érvényesül.

A prototipikus egyszerü múlt a 19. századi használatban, szembeállítva az elbeszélő múlttal, a következőképpen jellemezhető (vö. Langacker 2002; Brisard 2002; Tolcsvai Nagy 2017b; Mohay 2018), függetlenül a folyamat határolt vagy határolatlan voltától és időtartamának hosszától:

- a folyamat múltbeli, tehát nem tapasztalható közvetlenül a beszélö által, nem a beszéd ideje alatt megy végbe, nincs megismerö közvetlenség, a konstruáló távolsága, vagyis a közvetett megismerés, a szemtanúság vagy az átélés hiánya a meghatározó;

- nincs közvetlen megfelelés pillanatnyi állapotonként, vagyis most-pontonként az elbeszélt folyamat és a megértés (a beszéd) folyamata között, azok 
nem párhuzamosak, a feldolgozó folyamatot csak egészben, de időbelifolyamat-jellegében dolgozza fel a megértő;

- egyértelmúen megmutatkozik az elbeszélt esemény múlt ideje és a beszéd jelen ideje közötti idöbeli különbség, valamint a körülmények, korok közötti különbség.

E tulajdonságokból eredhet a „,befejezett” hatás.

A prototipikus elbeszélő múlt a 19. századi használatban, szembeállítva az egyszerü múlttal, a következőképpen jellemezhető, függetlenül a folyamat határolt vagy határolatlan voltától és időtartamának hosszától:

- viszonylag rövid, a konceptualizáló szeme előtt lezajló időhorizont a jellemző (Luhmann 1998: 1008);

- az elbeszélt esemény múltbeli, a beszélő nézőpontja az esemény elbeszélésében mégis belülről érvényesül, a meghatározó a megismerő közvetlenség, vagyis a konstruáló közelsége, a közvetlen tapasztalása, a szemtanúság vagy az átélés megléte, mintha a beszélö közvetlenül tapasztalná a felidézett eseményt, annak idejét;

- közvetlen megfelelés van pillanatnyi állapotonként, vagyis most-pontonként az elbeszélt esemény és a megértés folyamata között, azok párhuzamosak, a múltbeli folyamatot pillanatnyi állapotonként dolgozza fel a megértő, a saját feldolgozásának pillanatnyi állapotaival párhuzamosan;

- a beszélői jelen és az elbeszélt múlt folyamata közötti távolság nincsen elötérbe helyezve időben, térben, körülményekben, kultúrában, mindez kívül esik a figyelmi hatókörön, éppen a közelség van jelölve, az, hogy a beszélö a múltbeli valóságban otthonos, a megkonstruált jelenet(sor), esemény számára ismert, köze van hozzá.

E tulajdonságokból eredhet a „folyamatos” hatás.

Hozzá kell tenni, hogy e két igeidő funkcionálásában további tényezők is szerepet játszanak. Ilyen az igék idő- és eseményszerkezete általában, illetve ilyen a 19. században még gyakori szenvedő szerkezet, a létigés múltak és a határozói igeneves időszerkezetek sora.

Kazinczy a Pályám emlékezete címü müvében igen sürün élt az elbeszélő múlttal, meglehetős, bár nem teljes következetességgel, de a fö irányt tartotta. Ebben a variabilitásban azt lehet tapasztalni, hogy az egyszerü múlt is elöfordul olyan helyeken, ahol az elbeszélő jöhetne. A múlt idők közötti szerepkülönbség a nézőpont-irányítás egyik fontos eljárása itt. Az egyszerü múlt azt jelöli, ami szokás, általános, hosszabb távú vagy hosszabb érvényü vagy lezárult a múltban. Az elbeszélö múlt ezzel szemben azt fejezi ki, ami közvetlen élmény, valós vagy elképzelt. A két igeidő közötti váltások egyfajta episztemikus közelítés-távolítás rendszerben, zoomolásként müködnek A fentebb (5)-ben idézett részlet ezt mutatja be. A közvetlenül tapasztalt és mintegy élőként felidézett epizódok elbeszélő múltban vannak megkonstruálva: 
(6) atyám ’s anyám látni jövének

aggodalom rohana rám

üresen jöve szekerek [szekerük]

ott maradék

elhala

hét élő gyermekkel hagyá

A közvetlenül nem tapasztalt és ezzel együtt lezárt epizódok egyszerű múltban vannak:

(7) még az nap haza tértek

Mentem én is

A váltott múlt idők a helyzet drámaiságát érzékeltetik azzal, hogy az elbeszélőt közvetlenül érintő (például a hozzá közeledő mozgás) vagy saját maga által végzett események a saját közvetlen tapasztalásában elbeszélő múltban vannak, miközben az elbeszélőt közvetlenül nem érintő események (például a tőle távolodó mozgás) egyszerü múltban. A Pályám emlékezete egy másik részlete szintén tisztán mutatja a két igeidő közötti funkcionális különbséget (473):

(8) „Bossányi Ferencnek ifjabb, sőt még férfiéveiben is, igen szép keze-írása volt, 's sorai egyenest folytak mind oldalt, mind legelé, mintha lineázva volna a' papiros: most reszkete jobbja, 's nagy fáradsággal, de még mindég egyenest és igen csinosan írt; 's ez miatt hol patvaristát tarta, még hivatalt nem viselvén is, hol írni-tudó inast".

Ebben a részletben az elbeszélő által Bossányi Ferencnek közvetlenül nem tapasztalt, megélt férfiéveiről egyszerü múlt időben szól az elbeszélő (,szép keze-írása volt”, ,sorai egyenest folytak”), amit viszont közvetlenül tapasztal, lát, azt elbeszélő múltban mondja, a megismerő közvetlenséget leképezve, megerösítve a most közvetlenségének múltbeliségével („,most reszkete jobbja”). Ehhez képest a „mindég egyenest és igen csinosan írt” habituális cselekvés, ezért egyszerü múltban lehet.

A Pályám emlékezete egyes részleteiből az igeidők alkalmazásával, a múlt idők funkció szerinti (bár nem szabály szerinti, de tendenciaszerü követésével) nem csupán az egyes eseményekhez való elbeszélői perspektíva válik az olvasó számára hozzáférhetővé, hanem egyúttal az a viszony is, amelyet az elbeszélő magának az elbeszélésnek a során magáénak tud, megkonstruálva az az episztemikus közvetlenség vagy közvetettség változataiban. Az ugyanis az elbeszélö én személyiségének összetevője, hogy mit tart magához közelinek, és mit nem, mi az, ami közvetlenül érinti őt személyében, és mi az, ami nem, ami semleges. A megismerö és az utólagos átélő közvetlenséget az elbeszélő múlt jelöli, míg a lezárt, befejezett múltat az egyszerü múlt, legalábbis az esetek nagy részében. 


\subsection{A társszereplők nyílt és szubjektivizációs minősítése}

A Pályám emlékezete itt vizsgálandó harmadik énkonstruáló eljárása a társszereplők nyílt és szubjektivizációs minősítése. Kazinczy elbeszélőként előszeretettel nyilatkozik azokról az emberekről, akikkel az évek során dolga volt, és nem csupán pozitív vagy negatív értékek szerint, hanem egyes karaktervonásokat is gyakran kiemel, tömören jellemezvén az illetőt. Ez az eljárás látszólag jellemzés és egyúttal viszonyépítés, vagyis annak általában rövid jelzése, hogy maga az elbeszélő milyen viszonyban állt a szóba hozott személlyel. Valójában azonban visszacsatol magának az elbeszélőnek a személyiségére is, e személyiség szövegbeli továbbkonstruálására. Az olvasó ekképp további árnyalatokat érthet meg az elbeszélő én személyiségvonásairól annak alapján, hogy milyen emberekhez miképp viszonyul, nyílt és bennfoglalt jellemzésekkel.

A (9) szövegrészletben jól azonosíthatók a minősítések, mind objektivizált, mind szubjektivizált formában (471-2).

(9) „Nagyatyám Bossányi Ferencz [...] Erkölcsei szeplőtlenek, gondolkozása magas, érzése hív és szent. Egyedủl abban gyenge, hogy hamar fellobbanásaiban villámlott és mennydörgött, mint az e' részben is híres Baranyi; mind ketten a' kor' szokása szerint, nem szív' vadságából. [...] Vagyonával keveset gondola; ménese, gulyája, nyájai öröméül voltak, nem hasznára; pásztorai a’ szerint számolának, a’ mint magoknak tetszett; legtetemesbb hívtelenségeiknek villámlás és mennydörgés volt büntetések, vagy a' szolgálatból kiesés."

Bossányi Ferenc jellemzésében az egyik fö összetevő a tárgyilagosság, az objektivizált jelzők alkalmazása. A szeplötlen, magas, hív és szent melléknevek közvetlenül, áttétel nélkül mutatják be azt a személyt, akit az elbeszélő nagyra értékelt. Emellett olyan kifejezések is olvashatók, amelyek a megismerő közvetlenségen alapulnak szubjektivizáltak. Ilyen kifejezés a villámlott és mennydörgött igealak, amely a leírt személy erős indulatait érzékelteti. Ezek az igék Bossányi Ferenc „hamar fellobbanásait" mint történő folyamatokat képezik le, az elbeszélő nézőpontjából, egész pontosan abban a módban, ahogy ezek az indulati kitörések közvetlenül érzékelhetők voltak az unoka számára, az indulat kifejezésének hangzó és látható öszszetevőjét előtérbe helyezve. Mindkét jellemzési mód metaforikus, de nem teljesen azonos jelleggel. A tárgyilagos melléknevek konvencionálisan metaforizálnak, itt kisebb a szemantikai távolság a két összekapcsolt fogalom (fizikai és morális tisztaság, térbeli magasság és nagy érték) között, amennyiben egyáltalán felidéződik a kiinduló fogalom. A szubjektivizáló igék esetében nagyobb a szemantikai távolság a természeti és az indulati kitörés között, a kifejezés - ebben a szerkezeti formában még inkább - egyedibb. A beszélői perspektíva, az implicit értékelés példabeli erősen szubjektivizált voltát erősíti a nyílt pontosítás, amely enyhíti a magatartás komolyságát: „nem szív’ vadságából”.

A(10) idézetében a finom ironizálás (a, ,literaturai dolgozás” idővesztés a pipázgatáshoz képest, Magyarország „,sivatag hotentóti föld”) szintén erősen szubjektivizált, 
amennyiben a visszhangszerkezetben éppen a mủvészet az értékes, az ország pedig tartogat értéket is (497):

(10) „Kineveztetésemet az iskolákhoz leginkább köszönhetém a’ Gróf Török Lajos’ atyai szeretetének, de literaturai dolgozásimnak is valamelly részben, a' mit sokan idővesztésnek néznek, ’s épen azok kik az agarázást, kártyázást, pípázgatást nem annak. Egy szomszédunk lehozá bécsből Czirjék Mihály Testőrt, mátkájával, hogy a' boldog pár, ha a' leány hozzá tudna szokni azon sivatag hotentóti földhöz a' mit Magyar országnak halla mondatni, állandó lakást vegyen benne. Látván ez hogy Czirjék olvas és ír, beszéllé neki hogy félórányira az ő lakásához is van egy ifju ember, ’s az is mindég írogat."

Harmadik példaként egy anekdotaszerü epizódot érdemes idézni (11)-ben, amelyben a történetben felbukkanó Voltaire elöször laza és patriarchális, de a kontextusban kissé ironizáló megnevezést kap (Öreg), majd az öreg Csábító kifejezés egyértelmüen implicit értékelést tartalmaz az elbeszélő részéröl, a csábitó melléknév többféle megértési lehetőségeiben, ismervén Voltaire életvitelét, nyilatkozatait és müveit (530):

(11) „Fekete a' maga franczia Verseit két Kötetben adta ki, M e s R h a p s o d i e s czím alatt, 's eggy példányát két általag Tokaji borral küldötte-meg Voltairnak. Az Öreg megköszönte a' kettős ajándékot, franczia atticismussal azt vetvén mellé, hogy bora jobb mint verse. - Így beszéllé nékem ezt Fekete; mások másként. Talán mivel a' mit én franczia atticismusnak nevezék itt, nekik gorombaságnak látszik. Kértem a' Generálist, engedje látnom az öreg Csábító' írását, de a' levél Fóton vala."

A Pályám emlékezete egyes részleteiben az elbeszélő a nagymértékben objektivizáció vagy szubjektivizációs minősítések alkalmazásával, azok egymással történő válogatásával, az elbeszélő nézőpont ilyen közelítő és távolító váltogatásával az egyes események társszereplőinek bemutatását adja, egyúttal e társzereplökhöz való viszonyát nyíltan vagy bennfoglalva jelzi, ekképp saját énjének nyelvi megkonstruálást így is végzi.

\section{5. Összefoglalás}

A tanulmány Kazinczy Ferenc Pályám emlékezete címü müvében az E/1. önreferáló és önreflexív konstruálási módjait, azon belül az ezekhez kapcsolódó, saját magára és a társszereplőkre vonatkozó szubjektivizációs elbeszélő módok, jellemzések, megjegyzések viszonyait elemezte, a kognitív nyelvtan elméleti és módszertani keretében.

Azt mutatta be, hogy a Pályám emlékezetében az elemi és az összetett jelentésképzésnek az aktusai közé tartozik az én önreferenciális és önreflexív megjelenítésének specifikus módja, az elbeszélés lehorgonyzó deiktikus igeidőinek (főképp a kétféle múlt időnek) az alkalmazása, valamint az események további résztvevőinek nyílt és implikált jellemzése, az elbeszélő hozzájuk való viszonyának szubjektivizációs módja. A müben a szubjektum-objektum racionalista eredetü, objektivista klasszi- 
cista szembenállása már nem éles, az eseményleírást a szubjektivizációs eljárások az irodalmiság felé viszik el, a konstruáltság, de nem a fiktivitás jelzéseivel.

A Pályám emlékezete felszín szerint az események mint életepizódok kronologikus elbeszélése, valójában azonban a mü az önmegfigyelés aktusaira is épül, amelyet a visszafogott, implikált bensőségesség jellemez, és ahol az élettörténet a személyiség története, de nem vallomás. Az összetettséget pontosan mutatja az E/1. kettős jellege:szabatosan kijelölö, a beszélőt színre vivő önreferáló és önreflexív elem, miközben egyúttal a háttérben marad nem önmagáról tudó résztvevőként.

A tanulmány az én szubjektivizációs megkonstruálásának három megvalósulási módját vizsgálta.

Az elbeszélő saját nézőpontja, saját kiindulópontja mint referenciapont nagymértékben meghatározza a konstruálás módját, a beszédmódot. A közvetlen élmények, tapasztalatok általi folyamatos reflexió és önreflexió, önmegismerés önreferáló bemutatásában saját személyiségét állítja fel az elbeszélő. Az elbeszélésben egyszerre érvényesül az érintett szereplőkkel szembeni elkülönülés, távolságtartás, egyben közvetlen együtt cselekvés, a beleélés, amely a vele megtörténet események további szereplöinek a nézőpontját is bennfoglalja.

A Pályám emlékezete egyes részleteiből az igeidők alkalmazásával a múlt idők funkció szerinti elbeszélői perspektívája válik hozzáférhetővé, és ezzel együtt az a viszony is, amelyet az elbeszélő magának az elbeszélésnek a során magáénak tud, megkonstruálva azt az episztemikus közvetlenség vagy közvetettség változataiban. Az elbeszélő én személyisége összetevőjének bizonyul az, hogy mit tart magához közelinek, és mit nem, mi az, ami közvetlenül érinti őt személyében, és mi az, ami nem, ami semleges. A megismerő és az utólagos átélő közvetlenséget az elbeszélő múlt jelöli, míg a lezárt, befejezett múltat az egyszerü múlt, legalábbis az esetek nagy részében.

Kazinczy müve nem csupán történeti forrás, nem is csak müvelödéstörténeti dokumentum vagy a magyar emlékirat-irodalom egy új fejezetének elsőrangú példája, hanem a felvilágosodás után kezdődő modernség személyiségkidolgozásának, énkonstruálásának élő szövege. További elemzésekre várnak Kazinczy más müvei, föképp az itt nem tárgyalt önéletrajzok és visszaemlékezések, illetve a levelezésnek legalább egy része, hasonló szempontrendszer szerint, a Kazinczyról alkotott kép további elmélyültebb kidolgozása érdekében.

\section{FORRÁS}

Kazinczy Ferenc 2009 [1828]. Pályám’ Emlékezete [I]. In: Kazinczy Ferenc: Pályám emlékezete. Sajtó alá rendezte: Orbán László. Debreceni Egyetemi Kiadó, Debrecen, 471-531.

\section{SZAKIRODALOM}

Aikhenvald, Alexandra Y. 2004. Evidentiality. Oxford University Press, Oxford.

Athanasiadou, Angeliki - Canakis, Costas - Cornillie, Bert 2006. Introduction. In: Athanasiadou, Angeliki - Canakis, Costas - Cornillie, Bert (eds.): Subjectification. 
Various paths to subjectivity. Mouton de Gruyter, Berlin, New York, 1-13. https://doi. org $/ 10.1515 / 9783110892970$

Athanasiadou, Angeliki - Canakis, Costas - Cornillie, Bert (eds.) 2006. Subjectification. Various paths to subjectivity. Mouton de Gruyter, Berlin, New York. https://doi. org/10.1515/9783110892970

Benveniste, Émile 1971. Subjectivity in Langauge. In: Problems in General Linguistics. University of Miami Press, Coral Gables, 223-30.

Brisard, Frank 2002. Introduction: The epistemic basis of deixis and reference. In: Brisard, Frank (ed.): Grounding. The Epistemic Footing of Deixis and Reference. Mouton de Gruyter, Berlin, New York, xi-xxxiv. https://doi.org/10.1515/9783110899801.xi

Gadamer, Hans-Georg 1984. Igazság és módszer. Gondolat, Budapest.

Gergely András (szerk.) 2005. Magyarország története a 19. században. Osiris Kiadó, Budapest.

Heidegger, Martin 1989. Lét és idő. Gondolat Kiadó, Budapest.

Kugler Nóra 2013. A szubjektivizáltság mutatói. Magyar Nyelvör 137: 8-30.

Kugler Nóra 2015. Megfigyelés és következtetés a nyelvi tevékenységben. Tinta Könyvkiadó, Budapest.

Langacker, Ronald W. 2002. Deixis and subjectivity. In: Brisard, Frank (ed.): Grounding. The Epistemic Footing of Deixis and Reference. Mouton de Gruyter, Berlin, New York, 1-28. https://doi.org/10.1515/9783110899801.1

Langacker, Ronald W. 2006. Subjectification, grammaticalization, and conceptual archetypes. In: Athanasiadou, Angeliki - Canakis, Costas - Cornillie, Bert (eds.): Subjectification. Various paths to subjectivity. Mouton de Gruyter, Berlin, New York. 17-40.

Langacker, Ronald W. 2008. Sequential and summary scanning: A reply. Cognitive Linguistics 19(4): 571-84. https://doi.org/10.1515/COGL.2008.022

Luhmann, Niklas 1998. Die Gesellschaft der Gesellschaft. Suhrkamp, Frankfurt am Main.

Lyons, John 1982. Deixis and subjectivity: Loquor, ergo sum? In: Jarvella, Robert J. - Klein, Wolfgang (eds.): Speech, Place, and Action. Studies in Deixis and Related Topics. Chichester, John Willey New York, 101-24.

Mohay Zsuzsanna 2018. Múltidö-használat a középmagyar korban. A múlt idök középmagyar kori funkcióinak vizsgálata. PhD-értekezés. ELTE, Budapest.

Nagy Levente 2007. Az emlékirat-irodalom. 1704: Bethlen Miklós Önéletírása. In: Szegedy-Maszák Mihály (szerk.): A magyar irodalom történetei. Gondolat Kiadó, Budapest, 555-67.

Orbán László 2009. Jegyzetek. In: Kazinczy Ferenc: Pályám emlékezete. Sajtó alá rendezte Orbán László. Debreceni Egyetemi Kiadó, Debrecen, 783-1403.

Szegedy-Maszák Mihály 1980. A magyar költészet főbb típusai a kései XVIII. és a korai XIX. században. In: Világkép és stílus. Magvető Könyvkiadó, Budapest, 37-74.

Tolcsvai Nagy Gábor 1996. Esztétikai világszemlélet - szekularizált eszkatológia. Kazinczy életmúvéröl. Protestáns Szemle, 77-90.

Tolcsvai Nagy Gábor 2017a. Jelentéstan. In: Tolcsvai Nagy Gábor (szerk.): Nyelvtan. Osiris Kiadó, Budapest, 207-466.

Tolcsvai Nagy Gábor 2017b. A múltak átalakulása. Jelentéstani és narratív lehorgonyzó módosulások a magyar múlt időkben a 18. század után. Magyar Nyelv 113: 10-26. https:// doi.org/10.18349/MagyarNyelv.2017.1.10

Tomasello, Michael 2002. Gondolkodás és kultúra. Osiris Kiadó, Budapest.

Traugott, Elizabeth Closs 1989. On the rise of epistemic meanings in English: an example of subjectification in semantic change. Language 65: 31-55. https://doi. org/10.2307/414841 
Wellek, René 1970. A History of Modern Criticism: 1750-1950. Volume one. The Later Eighteenth Century. Jonathan Cape, London.

\author{
Tolcsvai Nagy Gábor \\ egyetemi tanár \\ Nyitrai Konstantin Filozófus Egyetem \\ Magyar Nyelv- és Irodalomtudományi Intézet \\ https://orcid.org/0000-0002-1780-3710
}

\title{
SUMMARY
}

Tolcsvai Nagy, Gábor

\section{Construing the subject in Kazinczy's memoirs Pályám emlékezete}

The paper discusses the methods of subjectification (in Langacker's term) in the written memoirs of the Hungarian poet and writer Ferenc Kazinczy entitled Pályám emlékezete, published in 1828. This volume has an intermediate character between the classical memoirs focusing on fate, history and those presenting individual, subjective processes and episodes of feelings, emotional reactions to events. Kazinczy worked out a particular way of linguistic construal, resulting in a complex structure. On the one hand, his life episodes are described from an objectivizing perspective, with the narrator as one participant of the events, although in first person singular. On the other hand, the events and the other characters are introduced via subjectified constructions. In this sense the paper analyses the functional use of the two Hungarian past tenses: the simple past and the imperfective past, the latter expressing epistemic immediacy, i.e. the narrator recounts a past episode as if it happened at the time of the narration. Also, objective and subjective methods of person evaluation by the narrator is demonstrated. It is pointed out that subjectified expressions contribute not only to perspectivizing narration, but to the implicit albeit fundamental construal of the narrating subject as an individual, as a personality, in particular. Objectification and subjectification are harmonized in the complex semantic and deictic instantiations of the first person singular forms, in the course of Kazinczy's discourse.

Keywords: construal, imperfective past, memoir, objectification, personality, subjectification 